\title{
Analysis of the Politics of Local Government Budgeting in Nigeria (1995-2011)
}

\section{Stephen Ocheni, Ph.D.}

Ministry of Foreign Affairs, Abuja stephenocheni@yahoo.com $+23480649596600$

Moses Atakpa, Ph.D.

*Basil C. Nwankwo, Ph.D.

Professor and Dean, Faculty of Management Sciences Kogi State University, Anyigba, Nigeria basil.nwankwoy2k@yahoo.com $+2348033216765$

* Corresponding Author

\section{Doi:10.5901/ajis.2013.v2n2p497}

\section{Abstract}

The poor performances of most local government councils in Nigeria had squarely centered around the politics of local government budgeting in the country. A cursory look at the project profile of all the local government councils in Nigeria pathetically reveals lots of abandoned, ill-executed and white elephant projects littered in the various local government areas (LGAs). The financial profile of most local government councils are poor, because of planned mismanagement arising from the unsuspected "financial padding," embedded in the politics of local government budgeting in Nigeria. The findings from the analysis of this politics of local government budgeting in Nigeria (1995-2011) reveals that the often much cries from the local government administrators in the country that this level of government is seriously under-funded and therefore, not capable of discharging its constitutional duties effectively and efficiently, are nothing but a façade. The analysis of our findings shows that local government councils are adequately funded from the statutory monthly allocations from the Federation Account and had adequate internal revenue generation sources provided for them by the Constitution. However, the finances of this level of government are frittered away and mismanaged through the nature of the politics which accompany its annual budget estimates, which most often are not objectively and rationally construed and executed. Consequently, it is recommended as a panacea to this disruptive and dysfunctional politics of the budgetary process in the local government councils in Nigeria; that the budget office of the State Government which has the immediate responsibility to oversee the affairs of the local government councils Nigeria, should use their budget experts and technocrats to ensure comprehensive review of estimates which local government councils should be directed to submit to the Office of the Accountant General of the State from henceforth. This is the only viable visible way for now, through which sanity and prudence could be brought to bear on the politics of local government budgeting in Nigeria as our analysis from 1995-2011, revealed.

\section{Introduction}

The topic of this study is both interesting and intriguing. Politics permeates all aspects of our life and the social fabrics of the society.

As we all know, local government occupies a central position in the socio-economic and political development of our country - Nigeria. In fact, to be precise, local government in Nigeria is the third tier of government. It is vested with certain powers and enormous responsibilities. For example, local governments have been granted full autonomy to exercise their powers and duties without undue interference from the states and federal governments. The statutory allocations from the Federation Account are now sent directly to the local governments. The local governments are also 
expected to augment the revenue from the statutory allocations through the internal sources which include: flat rate, property rate, motor park fees, market fees, liquor license fees, fines and fees, etc. This is to mention but a few.

Revenues from the statutory allocations and the internal sources are meant to assist the local government in the discharge of some of its important or primary responsibilities which include - delivery of effective services at the grassroots, mobilization of rural masses for rural development, promotion of grassroots democracy and local participation and training in politics. Other responsibilities of the local government, according to Oladimeji Aborisade (1985:2), are: community development, maternity centres and dispensaries, ambulance service, night-soil removal and disposal, environment sanitation, cemeteries/burial places, public taps, public libraries, etc.

There is no doubt that local governments are vested with enormous powers and responsibilities as a third tier of government but regrettably, they have not been able to live up to expectations. A lot of explanations have been proffered why the local government is not able to perform effectively and efficiently as an important level of government at the grassroots. Some of the reasons given for the poor performance is lack of adequate financial support from the higher tiers of government which are the state and the federal governments. Secondly, lack of adequate autonomy for the local governments has been mentioned. This implies excessive control from the higher tiers of government. Thirdly, lack of qualified and experienced manpower is also responsible. Finally, political instability within the local government system and the general body politic of the country is another reason.

The critics of the above reasons for poor performances of the local governments argue that local governments receive adequate financial support from the higher tiers of government (States and Federal). Furthermore, they stress that local governments have many sources of internal revenue generation, full political and legal autonomy and qualified manpower, etc. But according to the critics the only problem affecting the local government is corruption. The critics are of the view that the whole machinery of the local government administration is corrupt. According to the critics the only solution to the problem is a complete overhaul of the local government set-up and constant education (by way of training, seminars, conferences, etc.) for the local government staff as a means of reorientation into the cardinal values of local government administration.

Be that as it may, there is one obvious thing that is very clear which is that our local governments are confronted by problems of different magnitudes and complexities. Furthermore, our local governments have performed at substandard level. Evidences abound that the lives of our rural masses have not significantly improved since the inception of the local governments. Therefore, it is more appropriate to examine the issue of poor performance of our local governments from the substructure instead of the superstructure as is the case now.

The success of any organization is finance just as economic resources are the bedrock of any society. How the available finance is managed is very crucial for the local governments to perform effectively, coherently and efficiently. Hence to understand the present poor performance of our local governments it is important for us to be familiar with the politics of financial management in the local government system which invariably is the politics of local government budgeting (estimates). This is the main focus of this study, that is, to examine the politics of local government budgeting (estimates) with a view to ascertaining the nature and character of the politics and the influences on the overall performance of the local government system in Nigeria.

\section{Conceptual Clarification of the Meaning of Budget (Estimates) in the Local Government System}

A budget, more popularly known in local government circles as annual estimates, is defined in its broadest sense as Halidu (1994:1) has done:

A conscious and systematic allocation of resources prepared in advance, relating to a future period, and based on a forecast of key variables adopted to achieve certain policy objectives, which may or may not set explicit performance targets for the achievement of objectives; relates anticipated expenditure to anticipated revenue and forms the bases against which actual expenditure and revenue can be measured and controlled.

Furthermore, a local government budget (estimates) is an annual comprehensive report of the state of the local government's financial position. It reviews old economic and social problems of the local government and also anticipates new ones. It surveys the future prospects of the local government's financial status and translates problems into goals or objectives. 
A local government estimates is also seen as a plan of action expressed in quantitative and monetary terms, covering a specified period of time. The period usually covered is one year and this makes it a short-term plan. Practically all local governments prepare annual estimates. To many local governments, annual estimates connotes a restraining influence on action, hence many local government staff either as individuals or members of organizations seem to develop a negative attitude to estimates. Since resources available are not always sufficient to service the needs or goals which the local government would like to serve, estimates remains the most tactical instrument for both decisionmaking as well as allocation of resources.

In a more general sense, a local government estimate is a document containing words and figures which proposes expenditure for certain items and purposes. The words describe items of expenditure such as salary, education, health services, public works and agriculture. And the figures are attached to each item or purpose. In a sense the estimates becomes a link between the financial resources and human behaviour in order to accomplish objective. Invariably those who prepare local government estimates intend that they should provide guide for future events and behaviour. In other words, a local government estimate is concerned with the translation of financial resources of the local government into human purposes. An estimate consequently may be characterized as series of goals with price tags attached; example, Education, Health, Transportation, Housing, Agriculture, etc.

Viewed yet from another angle, a local government estimate may be regarded as a form of contract. The executive arm of the local government and the legislative arm (Council) agree to make money available under specified conditions, while the various departments and units agree to spend the funds in ways that have been agreed upon.

Consequently, a local government estimate is not merely one way process in which the executive arm makes proposal, the legislature (Council) authorizes, but a joint exercise, by the executive, the legislature and the departmental heads - the executive prepares the estimate, the legislature authorizes, while the departmental heads implement. To the extent that an estimate is carried or passed it imposes a set of mutual obligations and control upon the contracting parties. In a sense local government estimates also serve as a communication network especially during their preparations, because each participant receives information on the preference of others and transmits his own preferences and interests through the decision and choices he makes. The estimates also serve as an instrument of control because limits are set on the amount of money specific departments, programmes, units, etc., can spend within a given financial year. They are not expected to incur extra or additional expenses without supplementary appropriations as virement is no longer tenable with the Revised Model Financial Memoranda. Recalcitrant chairman or heads of department can be disciplined through substantial cuts in their future estimates. The budgetary process (estimates) in the local government is an exercise which generates interests among varied groups such as those members of the council, executives (chairman), professional bodies, traders, contractors and, in fact, the ordinary citizen. This is so because the fundamental question of "who gets what?" that a local government has to face is answered in typical local government estimates. The estimates have become, in several local governments, significant statements of fundamental policies of the local government often presented with a considerable wealth of judgment, reflection and imagination. The local government estimates also have been said not to be merely matters of arithmetic and dry statistical figures, but in several ways, a representation of the main desire, interests and hopes of the local masses. The budgetary (estimates) process in the local government is usually an annual affair. The estimates therefore, should contain all the financial provisions needed for a particular year. It publicizes the activities of the local government as well as instills responsibility and accountability in the local government structure and expenditures.

\section{The Politics of Budgeting in the Nigerian Local Government System}

To understand the nature and character of politics that underline most local government estimates in Nigeria, it is necessary to first of all know the structure and organization of the estimates as provided for under the law. What this implies is that if we can understand the framework and purpose of the estimates as well as how the estimates are prepared, amongst other things, we will be in a better position to appreciate the politics of budgeting in the local government system, especially in Nigeria.

It is interesting to note that the Revised Model Financial Memoranda for Local Government (Second Edition) as provided by the Federal Republic of Nigeria has exhaustively dealt with and explained the nature, structure and organization of local government estimates in Nigerian local governments. This has made our work simpler. We are, therefore, going to restate some of the important provisions of the local government estimates as provided for in the revised Financial Memoranda (FM). When this has been done, we shall then examine the place of politics both in the 
articulation, preparation and implementation of the approved estimates. We shall also, based on our discussions, explain why local governments in Nigeria over the years have assumed a character that makes it difficult for the objectives of the estimates in particular and the local governments in general to be realized.

\section{The Structure and Organization of Local Government Estimates in Nigeria under the Revised Model Financial Memoranda (FM)}

The structure and organization of local government estimates under the Revised Model Financial Memoranda for Local Government in Nigeria (Second Edition, 1991), are unique. They are significantly different from those of the states and federal government which are higher tiers of government. According to the Revised Model Financial Memoranda, the provisions of local government law regarding local government annual estimates provides that

(1) Every department of Local Government shall in each year:

a) Cause to be prepared in accordance with any directions made in that behalf by the executive committee, a detailed estimate of its revenue and expenditure for the next ensuing financial year;

b) Submit the estimate to the executive committee which shall consider it in order to ensure that it is not inconsistent with the general budgetary measures adopted by the local government and the state for the succeeding financial year; and in any case where the estimate is found inconsistent the executive committee may give such directives as may be appropriate in the circumstances to the government department concerned and the department shall comply with such directives.

(2) The executive committee shall submit the estimate to the local government council which shall consider and approve with or without modifications. The objectives of the annual estimates as outlined in the revised Model Financial Memoranda include:

a) To provide a financial plan of action: The estimates are a statement of the objectives of the local government in financial terms for the financial year concerned, and are in effect the local government's working plan for the year. The activities of the local government must be conducted within the financial framework prescribed by the estimates, as they are finally approved, unless and until supplementary estimates are approved which would vary the original framework;

b) To provide legal authority for incurring expenditure: As the estimates are a financial plan of action for the year, their formal approval in accordance with the provisions of the law is the legal sanction for the expenditure envisaged by the estimates. Any expenditure must be covered by a provision in the annual or supplementary estimates, failing which it is unlawful;

c) To provide a mechanism for ensuring that adequate controls are maintained over expenditure and revenue: Having established a financial framework for action, the estimates are then to be used as a mechanism for ensuring that adequate controls are maintained over expenditure and revenue. Because the local government accounting system is directly related to the heads and subheads of the estimates, when the amount spent under any subhead gives an indication of being likely to exceed the approved estimates, the control arrangements must be such that prompt steps are taken either to obtain a supplementary authorization, or to contain expenditure within the expenditure limit provided in the approved estimates;

d) To establish the financial position of the local government: The estimates must reveal, taking the expenditure and revenue figures together, the estimated financial position of the local government at the beginning and end of the appropriate financial year, on the assumption that revenue and expenditure proceed on the basis set out in the estimates. This enables the soundness, or otherwise, of the financial position of the local government to be gauged.

The Revised Model Financial memoranda also provided a framework for the local government estimates. Under the framework it stated:

Financial estimates, accounts and statistics of local governments, if they are to be of real use in local governments, must be based on a standard pattern of classification of revenue and expenditure. A standard framework or code has, therefore, been prescribed to apply to both the estimates and the accounts of local government. 
Local government estimates as provided for in the revised Model Financial Memoranda are prepared on a programme budgeting basis under which homogenous activities are grouped together into a programme. Each programme has the following objectives:

(a) To become the cost centre for collecting details during the preparation of annual estimates;

(b) To be the control centre during the implementation of the approved annual estimates and financial accounting purposes;

(c) To become reference points during reviews of the annual estimates and for the purpose of audits of financial transactions.

To help ensure that the estimates provide a sound means of financial control over local government expenditure, the revised Model Financial Memoranda provided the following general rules for their preparation:

(1) The annual estimates shall not provide for alterations in the existing approved level of the following items unless alterations are specifically approved by the councils:

(a) Salaries and allowances of members of the local government council. For this purpose, allowances include monthly and annual allowances, sitting fees, transport and traveling allowances and all other payments or reimbursements claimed by the chairman, councilors and the supervisors or paid to them by local government;

(b) Grading of the posts of secretary, clerk of council, heads of department and, where appropriate, district/village heads.

(2) The local government may make provision in the estimates for:

(a) Official hospitality;

(b) Official presents;

(c) Ceremonial expenses.

The governor shall issue directives specifying the maximum provisions that may be made in respect of the foregoing items. The sum of the provisions made by the local government under all heads in the annual estimates in respect of these items, shall not exceed the maximum determined by the council.

(3) No expenditure in excess of the approved estimated amount, whether by way of increases in the amount approved for a particular head or subheads, shall be incurred unless approved by the appropriate authority as set out in Chapter 4 of these Financial Memoranda.

(4) Unexpended balances of vote estimates shall only be used to meet expenditure on other votes during the same financial year when approval to such action is given by the appropriate authority as set out in Chapter 4 of these Financial Memoranda.

(5) Unexpended balances of vote estimates at the end of a financial year shall not be carried forward to the following year except as provided in Financial Memorandum 27.11.

(6) Subject to the appropriate provisions of the law, any expenditure which is incurred in excess of the approved estimates and which has not been approved by the appropriate authority, shall be chargeable to the chairman, supervisors, councilors or officers who have directed or allowed the authorized expenditure, and they shall be held personally liable for the excess expenditure.

For the recurrent revenue estimates the revised Model Financial Memoranda provided that the annual recurrent revenue estimates of local governments shall be prepared under the following heads:

Head 1001 Taxes

Head 1002 Rates

Head 1003 Local Licenses, Fees and Fines

Head 1004 Earnings from Commercial undertakings

Head 1005 Rent on Local Government Property

Head 1006 Interest Payments and Dividends

Head 1007 Grants

Head 1008 Miscellaneous

Head 1009 Statutory Allocations

Furthermore, for recurrent expenditure estimate, it provided that the annual recurrent expenditure estimates of local governments shall be prepared under the following heads: 
Head 2001 Office of the Chairman

Head 2002 Secretary to the Local Government

Head 2003 The Local Government Council

Head 2004 Personnel Management

Head 2005 Finance

Head 2006 Education

Head 2007 Medical and Health Services

Head 2008 Agriculture, Natural Resources and Social Development

Head 2009 Works, Housing, Land and Survey

Head 2010 Traditional Offices (where applicable)

Head 2011 Miscellaneous

Head 2012 Contribution to Local Government Loans Fund

Head 2013 Transfer to Reserve Fund

The capital receipts estimates of the local government as provided for in the Financial Memoranda (FM) are prepared under the following heads:
Head 3001 Internal Sources
Head 3002 External Sources
Head 3003 Grants
Head 3004 Miscellaneous

The capital expenditure estimates as provided for in the FM are prepared under the following heads:

(1) Economic Sector:

Head 4001 Agriculture and Rural Development

Head 4002 Livestock

Head 4003 Forestry

Head 4004 Fisheries

Head 4005 Manufacturing and Crafts

Head 4006 Rural Electrification

Head 4007 Commerce, Finance, Cooperatives and Supply

Head 4008 Transport (Roads and Bridges)

(2) Social Services Sector

Head 5001 Education

Head 5002 Health

Head 5003 Information

Head 5004 Social Development, Sports and Culture

(3) Area Development Sector

Head 6001 Water Resources and Water Supply

Head 6002 Environment, Sewage and Drainage

Head 6003 Town and Country Planning

Head 6004 Community Development

(4) Administration Sector

Head 7001 General Administration (Office Buildings)

Head 7002 Staff Housing

Head 7003 Workshop

(5) Repayment of Capital Loan Sector

Head 8001 Repayment of Loans and Interests 
Also, the revised Model Financial Memoranda (MFM) provided a set of standard and appropriate forms for the recording and preparation of the annual estimates of local governments. Example of some of these forms is LGT 1-9.

The revised MFM also provided adequate time-table for the preparation of annual estimates of the local government. For example in its Chapter 3, the FM states as follows:

To ensure that the annual estimates are approved by the council before the commencement of the financial year to which they relate, a strict time-table shall be adhered to for each stage involved in the preparation of estimates and the latest date for the completion of each step shall be as set out in this chapter of the financial memoranda.

The first step in the preparation of the annual estimates is the local government executive committees call circular. The FM provides that the local government executive committee shall issue a circular calling for the preparation by local governments of estimates for the ensuing financial year. Such circular shall be issued in such time as to reach each department to which it is addressed, by $1^{\text {st }}$ June. The call circular shall:

(1) contain such general guidelines to be followed by departments in the preparation of their annual estimates as reflected the local government's policy and priorities in regard to the discharge of functions and provisions of services at the local level;

(2) stress such procedural and timing matters and matters related to the objectives and content of estimates, as are considered appropriate by the executive committee.

Financial Memoranda 3.3 provides for the treasurer's call circular. It states that immediately on receipt of the Executive Committee's call circular and not later than $10^{\text {th }}$ June, the treasurer shall issue an estimates call circular to heads of department. This call circular shall:

(1) Indicate the last date ( $10^{\text {th }}$ July) by which departmental estimate proposals must reach the Finance Department;

(2) Incorporate the content of the call circular issued by the Executive Committee in accordance with the provisions of Financial Memoranda 3.2;

(3) Refer to any policy decisions reached by the council in regard to the content of the estimates and the priorities to be reflected therein;

(4) Refer to any directions of the Executive Committee regarding the detailed procedures to be followed in estimates preparation;

(5) In the light of experience in the preparation of estimates for previous years, incorporate such other procedural matters as appear to the treasurer to be likely to facilitate the preparation and subsequent processing of departmental estimate proposals.

The Financial Memoranda 3.4 provides for the preparation and submission of departmental estimate proposals to the treasurer. It states that under the general direction of the appropriate supervisor, the head of department shall prepare estimate proposals for each of the services concerned. The estimate proposals shall comprise:

(1) Estimates of the revised revenue and expenditure (recurrent and capital) for the current year;

(2) Estimates of the revenue and expenditure (recurrent and capital) for the following financial year.

Financial Memoranda 3.5 provides that the departmental estimate proposals supported by full explanatory notes shall be forwarded to the treasurer by $16^{\text {th }}$ July.

FM 3.6 also provides that estimate proposals in respect of revenues (See FM 2.2) and for other heads of revenue not covered by FM 3.4, shall be prepared by the treasurer by $10^{\text {th }}$ July. The treasurer shall base such revenue estimate proposals on the existing levels of taxes, rates, licenses, fees and rents but, will take account of anticipated increases in the number of tax payers, and of persons paying rents, fees, etc.

Furthermore, FM 3.7 provides for the treasurer's summary of departmental estimate proposals. It states that not later than $31^{\text {st }}$ July the treasurer shall consolidate the estimate proposals of departments, including the finance department and submit them through the Secretary for consideration by the Executive Committee. To accompany the estimate proposals, the treasurer shall prepare:

(1) In accordance with the provisions of FM 1.14(2) a report on the general financial implications of the estimate proposals and the effect they will have on the financial situation of the local government;

(2) A preliminary summary of the financial position on Form LGT 10 containing the following information:

(A) Transactions for Year of Estimate

(a) Estimated recurrent expenditure

(b) Estimated capital expenditure

(c) Estimated capital revenue 
(d) Estimated capital expenditure to be met from recurrent revenue (B-C)

(e) Total estimated expenditure to be met from recurrent revenue (A-D)

(f) Estimated recurrent revenue

(g) Estimated surplus/deficit on transactions for year 20

\section{(B) Effect of Transactions for Year of Estimate on Overall Financial Position}

(h) Estimated reserves at the end of current year 20

(i) Add estimated surplus or deduct estimated deficit as in (G) above

(j) Estimated reserves at end of year of estimate 20

(k) Working capital required __ \% of estimated recurrent expenditure as in (A) above

The FM 3.8 provides for consideration of departmental estimate proposals by Executive Committee and the council. It states that the Executive Committee shall consider the estimate proposals, and the report and summary prepared by the treasurer in accordance with the provisions of FM 3.7. The Committee shall hold such discussions with heads of departments as it considers necessary to clarify provisions made in the estimate proposals. Where the summary on Form LGT 10 shows that the estimated recurrent revenue is not sufficient to meet the total estimated expenditure shown in the summary as to be met from this source, the executive committee shall examine:

(1) The extent to which the excess of capital expenditure over capital revenue can be defrayed from sources other than recurrent revenue, that is from reserves or by raising loans, or by applying for a capital grant from the state government;

(2) The additional recurrent revenue which will still be needed after allowing for possible adjustments as in (1) above, to meet all estimated expenditure requirements. Similarly, FM 3.9 states that when considering the estimated amount of recurrent expenditure that can be met from estimated revenue, the Executive Committee shall in respect of any new developments or extensions of service which operate for only part of the year of estimate, take into account not only the estimated recurrent cost in the first year of operation, but also the increased expenditure which will be incurred in future years when such developments or extensions of service are fully operative. Where the Executive Committee has doubts about the local government's ability to meet the eventual full annual recurrent costs of the development or extension of service, then such development or extension must be postponed pending a further appraisal, even though the recurrent cost for part of a year could be met in the estimates under consideration.

Also, FM 3.10 provides that the Executive Committee shall then decide following its examination of the overall estimate situation in accordance with the procedure prescribed in FM 3.8 and 3.9:

(1) Whether, in order to eliminate the excess of expenditure to be financed from recurrent revenue over the amount of such revenue, the departments of the local government should be asked to reconsider their estimate proposals with a view to effecting reductions. Where the Executive Committee resolves to proceed on this basis, to shall issue guidelines to the departments indicating the extent of the economies it considers essential to achieve. Such guidelines may refer to a percentage reduction in total estimated departmental expenditure or, alternatively, some aspects of estimated departmental expenditure, or may indicate the estimated total amount by which it is proposed that estimated departmental expenditure should be reduced;

(2) Whether, in order to remedy a shortfall in recurrent revenue, to recommend to the council that steps should be taken to raise additional revenue and, if so, to prepare the Executive Committee's proposals in this regard for approval by the council;

(3) Whether to proceed on the basis of both (1) and (2) above.

Similarly, FM 3.11 provides that if, following the procedures outlined in FM 3.10, the estimates can be satisfactorily adjusted so that recurrent revenue will be sufficient to meet all requirements, the amended estimate proposals shall be submitted to the council by $31^{\text {st }}$ August accompanied by full explanatory notes and a report of the Executive Committee on:

(1) The revised estimated financial position at the end of the present financial year; 
(2) The financial implications of the estimates of revenue and expenditure for the next financial year and any special factors involved;

(3) Any proposed increases in taxes, rates, license fees, rents or charges for local government services.

FM 3.12 provides for approval of estimates by local government council. It states that the Council shall consider the draft estimates or amend draft estimates, as may be appropriate, together with the report of the Executive Committee, at a meeting to be held not later than $15^{\text {th }}$ December. After a further review of the measures necessary to achieve a sound financial position and to provide adequate funds for implementing Council's policies, the Council shall:

(1) Approve the draft estimates as they stand or with such amendments as the Council may think fit;

(2) Approve such increases in taxes, rates, licenses, fees, rents and charges as the Council considers appropriate.

The estimates then become the approved annual estimates of the local government for the appropriate financial year. However, increases in fees or new fees, etc. imposed under local government bye-laws/rules may not be collected until the bye-laws/rules have been approved.

FM 3.13 provides for forwarding of approved estimates to Governor. It states that following its approval of the annual estimates, the Council shall forward copies of the approved estimates to the Governor as indicated in the call circular not later than $31^{\text {st }}$ December.

Finally, FM 3.14 provides for implementation of estimates. It states that the approved annual estimates shall be implemented with effect from the first day of the financial year to which they relate.

We have carefully described the budgetary processes in the local government system as set out by the Revised Model Financial Memoranda (MFM). From close observation one would discover that the budgetary processes as outlined in the MFM is very detailed and if consciously and carefully observed within the local government circle will result in effective and efficient management and control of the financial resources of the organization. The question then is, why in spite of the articulate and coherent guidelines provided for preparation and execution of the local government estimates as provided in the revised MFM the local governments are yet to instill the culture of discipline and accountability in the management of their financial resources? The reason why the local government estimates is unable to achieve most of the target objectives and prudence in the management of the financial resources is because of the nature of politics that usually underlie both the preparation, approval and execution of the estimates. Our main task now is to examine the nature and character of this politics and its effects on local government performance.

\section{The Political Dimensions of the Local Government Estimates in Nigeria}

The politics of local government budgeting (estimates) in Nigeria centres around the human desires or preferences that underlie the preparation, approval and execution of the budget. As Aaron Wildavsky (1964:5) pointed out:

Human nature is never more evident than when men are struggling to gain a larger share of funds or to apportion what they have among myriad claimants. Budgeting deals with the purposes of men. In other words how can they be moved to cooperate? How can they find ways of dealing effectively with recalcitrant problems? Serving diverse purposes, a budget can be many things: a political act, a plan of work, a prediction, a source of enlightenment, a means of obfuscation, a mechanism of control, an escape from restrictions, a means to action, a brake on progress, even a prayer that the powers that be will deal gently with the best aspirations of fallible men.

The politics of local government budgeting emphasizes the human and behavioural aspects of the estimates. It specifically concerns with answering the question of "who gets what, how, when and why" of the local government financial resources. It is important to note that the purposes of a local government estimates are as varied as the purposes of men.

For example, one local government estimates may be designed to coordinate diverse activities so that they complement one another in the achievement of common goal. Another local government estimates may be put together primarily to discipline subordinate officials (departmental heads) within the local government system by reducing amounts for their salaries and their pet projects. And a third local government estimates may be directed essentially to mobilizing the support of the local groups who benefit by the services that the local government provides. Nothing is gained therefore, by insisting that a local government estimates is only one of these things when it may be all of them or many other things as well; one may, however, adopt a particular view of the local government estimates as most useful for the purposes he has in mind. For the purposes of our present discussion we would like to see the local government budget and the budgetary process as a phenomenon of human behaviour in a governmental setting. Throughout this work we 
shall be concerned with local government budgets (estimates) as political things. For example, taken as a whole the local government estimates in Nigeria is a representation in monetary terms of all local governmental activity. If politics is regarded in part as conflict over whose preferences shall prevail in the determination of local needs, then the local government estimates record the outcomes of this struggle.

If one asks, "who gets what the local government has to give?" then the answers for a moment in time are recorded in the local government estimates. If one looks at politics as a process by which the local government mobilizes resources to meet pressing problems, then the estimates area focus to these efforts.

The size and shape of the local government estimates are a matter of serious contention in the political life of the local people. The local chiefs, the chairman of local government, the political parties, administrators, councilors, community leaders, assembly members, interest groups, and interested citizens vie with one another to have their preferences recorded in the local government estimates. The victories and defeats, the compromises and the bargains, the realms of agreement and the spheres of conflict in regard to the role of the local government in the community all appear in the budget. In the most integral sense the local government estimates lie at the heart of the political process. It is this understanding and analyses of the human behaviour and the politics that underlay the formulation and execution of the local government estimates is what are usually referred to as "the politics of local government budgeting."

\section{Conclusion}

A local government budget (estimates) is not merely a matter of arithmetic and dry statistical figures, but in several ways embodies or represents the main desires, interests and hopes of the local people. This explains why the federal government may set out a detailed guidelines for the preparation, approval and implementation of the local government estimates as is in the revised Model Financial Memoranda (MFM), yet the actors and participants in the local government budgetary process would find a way to circumvent most of these guidelines in order to accommodate some of their hidden interests especially ones with political undertone.

The local government chairman, for instance, may have the interests of his party and the electorate who voted for him to protect but this may not be possible within a budget (estimate) with very rigid guidelines. This may also be applicable to the councilors and other actors within the budgetary process. There is, therefore, a need for a mutual agreement by the actors in the budgetary process to make certain compromises and sacrifices in order to accommodate the varied and divergent interests of each other. This obviously will entail ignoring some of the rigid and tight budgetary control measures by the actors and participants in the budgetary processes.

This may involve the use of different strategies such as lobbying, promise of award of contracts, promotion, dialogue, intimidation, appeal, etc. to outright bribery or offer of money or other rewards in kind. This is where the politics of local government budgeting really lies. In other words the manipulation of local government estimates to serve one political desires or the other. It is the satisfaction of the myriads of these hidden agendas by the actors in the politics of distribution of local government financial resources that often results in the poor performance of these local governments. Hence, the reasons often adduced and generally accepted for poor performance of the local governments in Nigeria is not only superficial but misleading. The true reason is masked and hidden, which is embedded under the politics of the local government estimates. In fact, it can only be discovered through a critical analyses of the personal and collective desires, interests and hopes of the actors in the local government budgetary processes and the masses they represent.

\section{References}

Aborisade, O. (1985). Financial Management of Local Government in Nigeria. Ile-Ife: Department of Local Government Studies, Faculty of Administration, University of Ife, lle-lfe.

Adebayo, A. (1969). Financing local government. Report of National Conference on the future of Local Government in Nigeria, Institute of Administration, University of Ife.

Adebayo, Adedeji \& Rowland (Eds., 1970). Local Government Finance in Nigeria: Problems and Prospects. University of Ife Press.

Egonmwan, J. A. (1984). Principles and Practice of Local Government in Nigeria. Benin City: S. M. O. Aka and Brothers Press.

Federal Republic of Nigeria (1991). Revised Model Financial Memoranda (Second edition). Government Press.

Gboyega, A. (1987). Political Values and Local Government in Nigeria. Lagos: Malthous Press Limited.

George, K. D. \& John, S. (1978). The Allocation of Resources: Theory and Policy. London: George Allen \& Unwin Limited.

Moak, L. L. \& Albert, M. H. (1978). Concepts and Practices in Local Government Finance. U.S.A. North Michigan Avenue, Chicago, Illinois. 
Nwosu, H. N. (1981). Public lecture on budgeting and financial management. In the Sub-Department of Public Administration and Local Government, University of Nigeria, Nsukka.

Onoh, J. K. (1980). The Foundations of Nigeria's Financial Infrastructure. London: Croom Helm Ltd.

Orewa, G. O. (1991). Principles of Local Government. Lagos: Administrative Staff College of Nigeria (ASCON).

Orewa, G. O. \& Adewunmi, J. B. (2011). Local Government in Nigeria. Benin City, Nigeria: Ethiope Publishing Corporation.

Oshisami, K. (1992). Government Accounting and Financial Control in Nigeria. Ibadan: Spectrum Books.

Sahni, B. S. (1992). Public Expenditure Analysis. University Press Montreal: Rottendam.

Sanford, C. T. (1978). The Economics of Public Finance. Oxford: Pergamon Press.

Strayer, P. J. (1958). Fiscal Policy and Politics. U.S.A.: Harper and Brothers.

Ugwu, I. (2012). Contemporary Issues in Local Government \& Democracy in Nigeria. Enugu, Nigeria: ACENA Publishers.

Wildavsky, A. (1964). The Politics of the Budgetary Process. Canada: Little, Brown \& Company Ltd. 
